\title{
In Vitro Embryo Production: Growth Performance, Feed Efficiency, and Hematological, Metabolic, and Endocrine Status in Calves
}

\author{
M. Rérat, ${ }^{1, \star}$ Y. Zbinden, ${ }^{1}$ R. Saner, ${ }^{2}$ H. Hammon, ${ }^{2,} †$ and J. W. Blum ${ }^{1}$ \\ ${ }^{1}$ Division of Nutrition and Physiology, Institute of Animal Genetics, Nutrition and Housing, \\ Vetsuisse Faculty, University of Berne, $\mathrm{CH}-3012$ Berne, Switzerland \\ ${ }^{2}$ Swissgenetics, $\mathrm{CH}-5243$ Mülligen, Switzerland
}

\section{ABSTRACT}

The potential management benefits of in vitro embryo production have been offset by an increased incidence of health-related problems in resulting calves [increased birth weight, congenital abnormalities, and peri- and postnatal mortality (large-offspring syndrome)] and of recipient cows (prolonged gestation, dystocia, increased hydroallantois, abortion). The aim of the present research was to determine whether relevant metabolic, endocrine, or hematological traits could be related to the causes of enhanced growth performance of in vitro fertilized calves. Growth performance and feed efficiency as well as hematological, metabolic, and endocrine traits studied in calves derived from in vitro-produced embryos (IVP; $\mathrm{n}=11$ ) and in calves derived from artificial insemination (AI; $\mathrm{n}=8$ ). Donor cows from which oocytes for in vitro fertilization were obtained had a heterogeneous background, thus excluding genetic maternal influences. On the other hand, semen for in vitro fertilization and for artificial insemination was from the same bull, and recipient cows were held under the same husbandry and feeding conditions as AI cows, thus reducing the variability. Blood samples were collected preprandially on d 1, 2, 3, 4, 7, 14, 28, 56, and 112 of life and every 20 min between 0830 and $1630 \mathrm{~h}$ on $\mathrm{d} 7$ and 112 for the evaluation of growth hormone secretory patterns. Gestation of IVP cows was longer than that of AI cows, but birth weights were similar in both groups. Feed intake, average daily gain, and body length during the experimental period, body weight from wk 8 to 16 , and gain/feed ratio during the first

Received July 30, 2004

Accepted March 13, 2005.

Corresponding author: J. W. Blum; e-mail: juerg.blum@itz. unibe.ch.

* Part of a thesis for Dr. Med. Vet., accepted by Vetsuisse Faculty, University of Berne, 2004. Current address: Federal Agricultural Research Institute, Agroscope Liebefeld-Posieux, CH-1725 Posieux, Switzerland.

$\dagger$ Current address: Forschungsinstitut für Biologie der Nutztiere, Forschungsbereich Ernährungsphysiologie “Oskar Kellner”, D-18196 Dummerstorf, Germany. month of life were higher in IVP than in AI calves. At birth, potassium, 3,5,3'-triiodothyronine, and thyroxine concentrations were lower in IVP than in AI calves. Concentrations of sodium and potassium on $d 7$, of triglycerides on d 28, and of albumin on d 56 were higher in IVP than in AI calves. In conclusion, IVP calves had higher feed intake and growth rate during the entire growth period and improved feed efficiency in the first month of life than AI calves, but this was not mirrored by consistent changes of hematological, metabolic, or endocrine traits, whose concentrations were in the normal range. Additional work is needed to study IVP calves under field conditions.

(Key words: calves, growth performance, metabolism, endocrinology)

Abbreviation key: $\mathbf{B E}=$ base excess, $\mathbf{G H}=$ growth hormone, IVP = calves derived from in vitro-produced embryos, $\mathbf{L O S}=$ large offspring syndrome, $\mathbf{M R}=$ milk replacer, $\mathbf{N f E}=$ nitrogen-free extract, $\mathbf{p} \mathbf{C O}_{2}=$ partial carbon dioxide pressure, $\mathbf{p} \mathbf{O}_{2}=$ partial oxygen pressure, $\mathbf{T}_{\mathbf{3}}=3,5,3^{\prime}$-triiodothyronine, $\mathbf{T}_{\mathbf{4}}=$ thyroxine.

\section{INTRODUCTION}

In vitro production (IVP) of calves has advantages for breeding programs because embryos can be gained from most donor cows, donors can be combined with many more sires, and more embryos can be obtained per time unit than with AI (van Wagtendonk-de Leeuw et al., 1998). However, several problems during gestation, calving, and postnatal life of IVP calves have been reported, such as increased birth weight (Walker et al., 1996), prolonged gestation period (Kruip and den Daas, 1997), dystocia (Hasler, 2000), a greater incidence of hydroallantois (van Wagtendonk-de Leeuw et al., 1998), increased incidence of abortions (Hasler et al., 1995), congenital abnormalities (Schmidt et al., 1996), and enhanced peri- and postnatal mortality (Behboodi et al., 1995). The "large offspring syndrome" (LOS) is of particular interest. Causes of LOS are thought to be factors present in culture systems used for preimplanted stages of embryos, such as high amounts of ammonia (McEvoy et al., 1997), enhanced 
activity of growth factors present in fetal serum used in culture media, and paracrine growth factor influences associated with embryonic cell interactions in the coculture (van Wagtendonk-de Leeuw et al., 2000). Possibly contributing to the development of LOS, embryonic manipulations (such as nuclear transfer) and the surrounding environment before implantation may result in inappropriate epigenetic modifications of imprinted genes and affect gene expression during later fetal development (Young and Fairburn, 2000; Young et al., 2001). To date, most studies on IVP calves have focused on the perinatal period, characterizing problems such as the viability of IVP bovine embryos (Taverne et al., 2002), abnormally high birth weight (Yang et al., 2001), calving, and metabolic and endocrine status (Jacobsen et al., 1999, 2000a,b, 2002; Sangild et al., 2000). Based on the few long-term studies during the postnatal period (McEvoy et al., 1998; ChavattePalmer et al., 2002), it is still not clear how IVP calves compare physiologically with AI calves. In the present study, the hypothesis was tested that apparently normal IVP and AI calves differ with respect to growth performance, feed intake, feed efficiency, and hematological, metabolic, and endocrine traits. Of prime interest were factors that are centrally involved in postnatal growth regulation, growth performance, body composition, and feed intake [growth hormone (GH), glucagon, IGF-I, insulin, leptin, 3,5,3'-triiodothyronine $\left(\mathbf{T}_{3}\right)$, and thyroxine $\left.\left(\mathbf{T}_{4}\right)\right]$.

\section{MATERIALS AND METHODS}

\section{Animals}

In vitro embryo production. Bovine ovaries were collected at random at a local slaughterhouse and transported to the laboratory in PBS to which $1 \%$ fetal bovine serum (FBS 2910149, ICN Pharmaceuticals, Orangeburg, NY) was added. Cumulus-oocyte complexes were collected through a filter, followed by washing of the filter with HEPES-buffered Medium 199 (Gibco BRL, Paisley, UK) that was supplemented with $10 \%$ fetal bovine serum at $25^{\circ} \mathrm{C}$. After transfer to 4-well dishes (Gibco, Basle, Switzerland), in vitro maturation was performed in $30-\mu \mathrm{L}$ drops of maturation medium (Medium 199; Sigma, Schnelldorf, Germany) supplemented with $15 \%$ fetal bovine serum, penicillin (60 UI/mL; Gibco), streptomycin $(60 \mu \mathrm{g} / \mathrm{mL}$; Gibco), and human chorionic gonadotropin (10 IU/mL, $5 \mathrm{IU} / \mathrm{mL}$ hCG, PG 600; Intervet, Boxmeer, the Netherlands) under paraffin oil (K 27537460; Merck, Darmstadt, Germany) for $24 \mathrm{~h}$ in an incubator with an atmosphere of $5 \% \mathrm{CO}_{2}$ in air.

Ova from the different cows were pooled before fertilization. The in vitro fertilization was performed in 30 - $\mu \mathrm{L}$ drops of fertilization medium (Le Gal and Massip, 1999). The semen was from a Limousin bull (name: Lemming; ID number: 910.0870.5426.2; origin: Switzerland). This bull was previously tested by the Swiss Simmental-Red Holstein breeder organization. The nonreturn rate of sired daughters was $-1.5 \%$, there were normal calvings in $94 \%$, and the bull enhanced net weight and carcass gain of his sons by $107 \%$. Frozen-thawed semen of this bull was layered on a Percoll solution (45 and 90\%) and centrifuged at $700 \times g$ for $30 \mathrm{~min}$. The sperm pellet was resuspended in $5 \mathrm{~mL}$ of sperm washing solution (fertilization medium without heparin) and centrifuged at $100 \times g$ for $10 \mathrm{~min}$. Sperm were added to the oocytes and coincubated under paraffin oil for $18 \mathrm{~h}$ in an incubator with an atmosphere of $5 \% \mathrm{CO}_{2}$ in air.

At the end of the fertilization process, presumptive zygotes were centrifuged to remove cumulus cells, washed 3 times in HEPES-buffered Medium 199 and then transferred in $30-\mu \mathrm{L}$ drops of modified synthetic oviductal fluid (SOFaa; Holm et al., 1999) that was supplemented with $5 \%$ fetal bovine serum. The in vitro culture was under paraffin oil for 6 to $7 \mathrm{~d}$ in an incubator with an atmosphere of $5 \% \mathrm{CO}_{2}$ and $5 \% \mathrm{O}_{2}$ in air. Only blastocysts of excellent quality were frozen and used for embryo transfer in 4 Simmental $\times$ Red Holstein, 1 Brown Swiss, 2 Holstein $\times$ Angus, 3 Brown Swiss $\times$ Blonde d'Aquitaine, and 1 Holstein $\times$ Blonde d'Aquitaine.

AI calves. Calves born by heifers and cows (9 Simmental $\times$ Red Holstein, 2 Holstein) that were inseminated by standard methods with semen from the same bull as above, served as controls.

Calvings. The calves, all mixed-breed, were born at the research station (Posieux, Switzerland) between August and December 2002. Eleven calves (6 males, 5 females) were single-born from the 11 IVP recipients. Calvings were unassisted except for one calf that required heavy extraction and one calf that was delivered by cesarean section. Eleven calves ( 3 males, 7 females, 1 stillborn) were single-born following AI. Calvings were unassisted except for one calf that required slight extraction and one calf that was stillborn after subcutaneous injection of prostaglandin $\mathrm{F}_{2 \alpha}(500$ $\mathrm{mg}$ of Cloprostenol, Estrumate; Essex, Friesoythe, Germany). One male AI calf was slaughtered on d 41 of life because of weakness and another calf on $d 27$ of life, and one AI female calf died at birth with neurological symptoms. The 3 calves were excluded from the study. Because of the loss of one calf at birth and 2 losses during growth, only 8 AI calves finished the trial. 
Table 1. Preprogrammed automate settings and contents of colostrum, colostrum powder, and milk powder.

\begin{tabular}{|c|c|c|c|c|c|c|c|}
\hline \multirow[b]{2}{*}{ Item } & \multirow[b]{2}{*}{ Day of life } & \multirow[b]{2}{*}{$\mathrm{BW}, \mathrm{kg}$} & \multirow{2}{*}{$\begin{array}{l}\mathrm{g} \text { of } \mathrm{DM} / \mathrm{kg} \\
\text { of colostrum } \\
\text { or milk }\end{array}$} & \multirow{2}{*}{$\begin{array}{l}\text { Available } \\
\text { milk, } \\
\text { kg/d }\end{array}$} & \multicolumn{2}{|c|}{$\begin{array}{l}\text { Available amounts } \\
\text { per portion, kg }\end{array}$} & \multirow{2}{*}{$\begin{array}{l}\text { Allowed } \\
\text { portions } \\
\text { per day }\end{array}$} \\
\hline & & & & & Min. & Max. & \\
\hline Colostrum & d 1 & & 250 & $10 \%$ of BW & & & \\
\hline Colostrum powder & $\begin{array}{l}\text { d } 2 \\
\text { d } 3\end{array}$ & & $\begin{array}{l}160 \\
130\end{array}$ & $\begin{array}{l}10 \% \text { of BW } \\
10 \% \text { of } \mathrm{BW}\end{array}$ & & & \\
\hline Milk powder & From d 4 & $\begin{array}{l}40-50 \\
50-60 \\
60-70 \\
70-80 \\
80-90 \\
90-100 \\
100-110 \\
110-120 \\
120-130 \\
130-140 \\
140-150 \\
150-160 \\
160-170 \\
170-180 \\
180-190 \\
190-200\end{array}$ & $\begin{array}{l}130 \\
130 \\
163 \\
163 \\
166 \\
167 \\
175 \\
181 \\
186 \\
190 \\
202 \\
214 \\
218 \\
230 \\
233 \\
245\end{array}$ & $\begin{array}{l}5.5 \\
7 \\
8 \\
9 \\
10 \\
11 \\
11.5 \\
12 \\
12.5 \\
13 \\
13 \\
13 \\
13.5 \\
13.5 \\
14 \\
14\end{array}$ & $\begin{array}{l}1 \\
1 \\
1 \\
1 \\
1.5 \\
1.5 \\
1.5 \\
1.5 \\
1.5 \\
1.5 \\
2 \\
2 \\
2 \\
2 \\
2 \\
2\end{array}$ & $\begin{array}{l}1.5 \\
1.5 \\
1.5 \\
2 \\
2 \\
2 \\
2 \\
2.5 \\
2.5 \\
2.5 \\
2.5 \\
2.5 \\
3 \\
3 \\
3 \\
3\end{array}$ & $\begin{array}{l}5 \\
6 \\
6 \\
6 \\
6 \\
6 \\
6 \\
6 \\
6 \\
6 \\
6 \\
6 \\
6 \\
6 \\
6 \\
6\end{array}$ \\
\hline
\end{tabular}

${ }^{1} \mathrm{DM}$ of colostrum and milk powder contained 45 and $21 \mathrm{~g}$ of water $/ \mathrm{kg}$, respectively.

\section{Husbandry, Feeding, and Experimental Procedures}

The experimental procedures followed the Swiss law on animal protection, were approved by the Cantonal Committee for the Permission of Animal Experimentation (Granges-Paccot, Switzerland), and were supervised by the Swiss Federal Veterinary Office (Liebefeld-Berne).

After birth, calves were weighed and their navels sprayed with an iodine solution (Betadine; Mundipharma Medical Company, Basle, Switzerland). They were separated immediately from their dams and held on straw in single boxes for $3 \mathrm{~d}$. Calves were then moved to 2 separate, but adjacent, loose housing systems with straw bedding and were held there until slaughtered at a BW of about $200 \mathrm{~kg}$.

On d 1 of life ( 1 and $8 \mathrm{~h}$ after birth), calves were bottle-fed colostrum that was collected from the first milking after parturition at a rate of $10 \%$ of $\mathrm{BW} / \mathrm{d}$. Colostrum was from a pool of cows of the research station and was prepared before the beginning of the study and stored in plastic bottles at $-20^{\circ} \mathrm{C}$ until used. Before feeding, colostrum was warmed to $40^{\circ} \mathrm{C}$ and then immediately fed. On d 2 and 3, calves were fed colostrum that was stored as powder (Col-o-Dan; Damino, Gesten, Denmark), in amounts of $10 \%$ of BW/d. Calves were fed by bottle twice daily, i.e., at 24, 32, 48 , and $56 \mathrm{~h}$ after birth. If a calf did not suckle, colostrum was given via an esophageal tube. On $\mathrm{d} 2$ and $\mathrm{d}$ 3 , the concentration of colostrum powder was 160 and $130 \mathrm{~g} / \mathrm{kg}$, respectively. From d 4 on, calves received milk replacer (MR) that was purchased as powder
(UFA 200 Natura, without antibiotics; UFA AG, Sursee, Switzerland) by suckling at an automate that was programmable for each individual calf (Stand Alone, Förster, Germany; program Kalbmanager 4.2) for $18 \mathrm{~h} / \mathrm{d}$. Automatic feeding started daily at $0830 \mathrm{~h}$. A daily 18-h feeding period was allowed and was divided in 6 periods of $3 \mathrm{~h}$. During each of these 3 -h periods, a limited portion (minimal and maximal amounts of portion, see Table 1) of the daily total amount of MR was available for every animal. When a calf drank its whole portion, it had to wait for the next period to get more feed. Concentrations of MR powder and available amounts of MR depended on BW. A detailed feeding plan with DMI, available amounts of MR, and amounts and number of portions are shown in Table 1. Daily rations were programmed every week based on the weekly-measured BW. Calves had free access to water and some hay from $\mathrm{d} 4 \mathrm{on}$.

The colostrum fed on d 1 contained $235 \mathrm{~g}$ of DM/kg and (per kg of DM) contained 24.9 MJ of gross energy, $555 \mathrm{~g}$ of CP, $265 \mathrm{~g}$ of crude fat, $104 \mathrm{~g}$ of nitrogen-free extracts (NfE; mainly lactose), and $75 \mathrm{~g}$ of crude ash. The colostrum powder contained $955 \mathrm{~g}$ of $\mathrm{DM} / \mathrm{kg}$ and (per $\mathrm{kg}$ of DM) contained 23.6 MJ of gross energy, 450 $\mathrm{g}$ of CP, $250 \mathrm{~g}$ of crude fat, $200 \mathrm{~g}$ of NfE, and $50 \mathrm{~g}$ crude ash. The MR contained $979 \mathrm{~g}$ of $\mathrm{DM} / \mathrm{kg}$ and (per $\mathrm{kg}$ of DM) contained 18.3 MJ of gross energy, $220 \mathrm{~g}$ of $\mathrm{CP}, 210 \mathrm{~g}$ of crude fat, $311 \mathrm{~g}$ of NfE, and $263 \mathrm{~g}$ of crude ash.

To protect against infections, calves were subcutaneously injected with $2 \mathrm{~g}$ of a bovine colostral immuno- 
globulin preparation (Gammaserin; Gräub AG, Berne, Switzerland) after the first blood sample was obtained. Additionally, calves were fed chicken-egg-derived immunoglobulins that contained high antibody titers against rotavirus and pathogenic Escherichia coli type K99 (Globigen 88; Lohmann Animal Health, Cuxhaven, Germany). Fed amounts were 10,8 , and $4 \mathrm{~g}$ on d 2,3 , and $\mathrm{d} 4$ to 7 , respectively. On d 2,3 , and 4 , calves were subcutaneously injected antibiotics $(25 \mathrm{mg}$ of enrofloxacin per $10 \mathrm{~kg}$ of BW, Baytril 5\%; Bayer AG, Leverkusen, Germany). If a hematocrit was lower than $0.3 \mathrm{~L} / \mathrm{L}$ on $\mathrm{d} 7$, calves were subcutaneously injected 600 $\mathrm{mg}$ of an iron preparation (Ferriphor $10 \%$; Lohmann Animal Health).

\section{Growth Performance and Health Status}

Body weight was measured weekly. Body length (distance from nose to the beginning of tail), chest circumference, and withers height were measured monthly.

Health status was evaluated and scored weekly based on the following clinical traits: rectal temperature, heart rate, respiratory rate, behavior (attentive or weak), eye and nasal discharge (none or present), lung noises (none or present), cough (none or present), fecal consistency (normal, thin, watery), navel and joints inspection (normal or inflamed).

\section{Blood Samples}

Blood samples $(10 \mathrm{~mL})$ were taken from the jugular vein with evacuated tubes on $\mathrm{d} 1,2,3,4,7,14,28,56$, and 112 of life. Additional blood samples $(2 \mathrm{~mL})$ were obtained every $20 \mathrm{~min}$ on $\mathrm{d} 7$ and 112 from 0830 to $1630 \mathrm{~h}$ from catheters that were inserted on d 6 and 111 into the jugular vein. Tubes containing dipotassium-EDTA (1.8 mg/mL of blood) were used for determination of plasma concentrations of glucose, triglycerides, NEFA, insulin, and glucagon on d 1, 2, 3, 4, 7, $14,28,56$, and 112 before the start of feed intake and at $1,2,4$, and $8 \mathrm{~h}$ after the start of feed intake on $\mathrm{d} 7$ and 112 . Tubes $(10 \mathrm{~mL})$ containing dipotassium-EDTA $(1.8 \mathrm{mg} / \mathrm{mL}$ of blood) were also used for the determination of preprandial values of total protein, albumin, urea, cholesterol, IGF-I, IGF-II, GH, leptin, $\mathrm{T}_{3}$, and $\mathrm{T}_{4}$ on $\mathrm{d} 1,2,3,4,7,14,28,56$, and 112 , and preprandial values of creatinine on $\mathrm{d} 1,7$, and 112 . Additionally, GH concentrations were measured in blood samples (tubes containing $1.8 \mathrm{mg}$ of dipotassium-EDTA $/ \mathrm{mL}$ ) taken at $0830 \mathrm{~h}$ and every $20 \mathrm{~min}$ for $8 \mathrm{~h}$ on $\mathrm{d} 7$ and 112 for the evaluation of secretory patterns. Tubes $(2 \mathrm{~mL})$ containing dipotassium-EDTA $(1.8 \mathrm{mg} / \mathrm{mL}$ of blood) were used on $d 1,7$, and 112 before the first meal for measurement of $\mathrm{pH}$, partial carbon dioxide pressure $\left(\mathbf{p C O}_{2}\right)$, partial oxygen pressure $\left(\mathbf{p O}_{2}\right)$ (both indicate the pressure of $\mathrm{CO}_{2}$ and $\mathrm{O}_{2}$ as part of a mixture of the other gases present in blood), base excess (BE), bicarbonate $\left(\mathrm{HCO}_{3}\right)$ concentration, hematocrit, hemoglobin, mean corpuscular hemoglobin, mean corpuscular volume, mean corpuscular hemoglobin concentration, and numbers of erythrocytes, leukocytes, neutrophils, monocytes, lymphocytes, and thrombocytes in whole blood. L-Lactate was determined in preprandial blood samples ( $2 \mathrm{~mL}$ ) obtained on d 1, 7, and 112 using evacuated tubes containing dipotassium-EDTA (1.8 $\mathrm{mg} / \mathrm{mL}$ of blood) and sodium fluoride $(3 \mathrm{mg} / \mathrm{mL}$ of blood). Tubes $(2 \mathrm{~mL})$ without anticoagulants were used to measure preprandial concentrations of calcium, phosphorus, magnesium, and iron in serum on $\mathrm{d} 1,2$, $3,4,7,14,28,56$, and 112 and of sodium, potassium, and chloride in serum on d 1, 7, and 112. Collected tubes containing anticoagulants were immediately put on crushed ice until centrifugation. Tubes without anticoagulants were stored at room temperature for 15 to $30 \mathrm{~min}$ before centrifugation. Tubes were centrifuged at $1000 \times g$ for $20 \mathrm{~min}$ at $4^{\circ} \mathrm{C}$. Supernatants (plasma or serum) were portioned into aliquots and stored at $-20^{\circ} \mathrm{C}$ until analyzed.

\section{Laboratory Analyses}

Blood analyses. Plasma concentrations of albumin, cholesterol, creatinine, glucose, L-lactate, total protein, triglycerides, urea, calcium, iron, magnesium, and phosphorus were measured using kits from BioMérieux, Marcy l'Etoile, France (kits \#61051, \#61218, \#61162, \#61269, \#61192, \#61602, \#61236, \#61974, \#61041, \#61075, \#61411, and \#61571, respectively), and NEFA with a kit from Wako Chemicals, Neuss, Germany (\# 994-75409) using photometric methods. For analysis of these traits, an automatic analyzer was used (Cobas Mira Plus; Roche, Basle, Switzerland). Concentrations of insulin, glucagon, IGF-I, $\mathrm{T}_{3}$, and $\mathrm{T}_{4}$ were measured by radioimmunoassay as described by Hadorn et al. (1997) and Hammon and Blum (1997, 1998).

Concentrations of GH were determined by radioimmunoassay as described by Hammon and Blum (1997, 1998). Intra- and interassay coefficients of variation were 8 and 13\%, respectively, and the sensitivity (limit of determination) was $0.5 \mathrm{ng} / \mathrm{mL}$.

For analyses of IGF-II by radioimmunoassay, human receptor grade IGF-II (used as standard and for iodinations) and an antiserum against human IGF-II (that was raised in a rabbit and that crossreacted by $85 \%$ with bovine IGF-II, but by less than $0.1 \%$ with human IGF-I and ovine insulin) were purchased from 
GroPep (Adelaide, Australia). The antiserum against IGF-II was used at a final dilution of 1:5000. Bovine IGF-I (10 $\mu \mathrm{L}$ of a solution containing $1000 \mathrm{ng} / \mathrm{mL})$ was added during incubations to displace IGF-II from binding proteins. The added amounts of IGF-I did not change binding of $\left[{ }^{125} \mathrm{I}\right]-\mathrm{IGF}-\mathrm{II}$ with the IGF-II antibody. Antibody-bound IGF-II was precipitated with antirabbit gammaglobulin, and bound fractions were separated by centrifugation at $1000 \times g$. The intraand interassay coefficients of variation were below 10 and $15 \%$, respectively. The sensitivity of the assay was between 20 and $30 \mathrm{ng} / \mathrm{mL}$.

For determination of plasma leptin concentrations in duplicates, a specific double-antibody radioimmunoassay was used as described by Blum et al. (2005). Briefly, ovine standards and $\left[{ }^{125} \mathrm{I}\right]$-labeled ovine leptin, antiovine leptin antiserum, and goat antirabbit IgG as second antibody were used.

For analyses of $\mathrm{pH}, \mathrm{pCO}_{2}, \mathrm{pO}_{2}, \mathrm{BE}$, and $\mathrm{HCO}_{3}$ in total blood, a portable clinical analyzer was used (iSTAT analyzer; i-STAT Corp., East Windsor, UK). To evaluate hematological status, an automatic analyzer (Cell-Dyn 3500; Abbott Laboratories, Abbott Park, IL) was used. To measure the concentrations of sodium, potassium, and chloride, an automated analyzer (Hitachi 912; Roche Diagnostics, Rotkreuz, Switzerland) was used at the Clinical Laboratory of the Faculty of Veterinary Medicine, University of Berne.

Analyses in colostrum, colostrum powder, and milk replacer. Chemical analyses were performed in duplicate in the routine laboratory of the Swiss Federal Research Station for Animal Production (Agroscope Liebefeld-Posieux, Switzerland), a certified reference laboratory for analysis of animal feeds. The same procedures were used previously (Hadorn et al., 1997; Hammon and Blum, 1998; Rauprich et al., 2000; Hammon et al., 2002). Samples of colostrum were lyophilized to determine DM (gravimetrically; $\mathrm{CV}<1 \%$ ), CP (by Kjeldahl method using photometrical determination; $\mathrm{CV}<0.8 \%$ ), crude fat (by the Berntrop method following protein denaturation by hydrochloric acid; $\mathrm{CV}<2.5 \%$ ), and crude ash (after combustion at $550^{\circ} \mathrm{C}$ for $4 \mathrm{~h}$; $\mathrm{CV}<2 \%$ ). Contents of NfE (mainly lactose) were calculated as the difference between DM and the sum of CP + crude fat + ash, and gross energy was calculated based on energy equivalents of 36.6, 17.0, and $24.2 \mathrm{MJ} / \mathrm{kg}$ of crude fat, $\mathrm{NfE}$, and $\mathrm{CP}$, respectively. Contents of CP, crude fat, and crude ash in colostrum and MR powder were provided by the manufacturers.

\section{Statistical Analyses}

Values are expressed as means \pm SEM. For group, sex, and time differences, parameters for growth per- formance, plasma concentrations of metabolic and endocrine traits as well as hematological and chemical traits were evaluated using the RANDOM and REPEATED methods of the MIXED procedure (Version 8.02; SAS Institute, 1994). Group, sex, and time were used as fixed effects and the individual calves were used as random effects. For the evaluation of group differences dependent on sex, group $\times$ sex interaction was included in the model. For the evaluation of differences between groups or sex at fixed time points, group $x$ time and sex $\times$ time interactions were included in the model. The given $P$ values were derived from $t$ tests using estimates after the Mixed model procedure and were considered significant if $P \leq 0.05$. The PROC GLM procedure (SAS Institute, 1994) was used to analyze gestation length and GH on d 7 and 112 .

Episodic secretion of GH (mean concentrations, peak amplitudes, and peak frequencies) were analyzed according to Merriam and Wachter (1982). This method removes long-term trends, such as diurnal rhythms, from the series of observations and calculates a base line by generating a smoothed series that omits peaks or trends with time constants less than 6 to $8 \mathrm{~h}$. It identifies peaks by criteria of height and duration of deviation from the base line, measured relative to the expected random variability of the series. The assay standard deviation used in the algorithm was modeled as a quadratic function of the $\mathrm{GH}$ concentration. The following cut-off $(G)$ values (peaks in SD units) that define peaks were used: $\mathrm{G}(1)=4.4, \mathrm{G}(2)=2.6, \mathrm{G}(3)=$ $1.92, \mathrm{G}(4)=1.46$, and $\mathrm{G}(5)=1.13$.

If a difference in sex affected growth performance, metabolic, endocrine, hematological, or chemical parameters, this effect is described in the text. Overall, data of males and females were pooled.

\section{RESULTS}

\section{Health Status, Gestation Length, and Growth Performance}

Calves were generally healthy, with few exceptions. The navel of one IVP calf was inflamed in wk 1, loose feces were apparent in wk 1 and 2 in one AI calf, and in wk 3 and 4 in one IVP calf. In wk 4, 8, 9, 10, and 16 , one IVP calf suffered pneumonia and, in wk 6 , one AI calf had similar symptoms. Five IVP and 3 AI calves were injected with iron because of a hematocrit level $<0.3 \mathrm{~L} / \mathrm{L}$ on $\mathrm{d}$ 7. The scored health status in IVP and AI calves was not significantly different.

Rectal temperature (at birth: $38.6 \pm 0.2$ and $38.3 \pm$ $0.1^{\circ} \mathrm{C}$ in IVP and AI animals, respectively; in wk 16 : $39.1 \pm 0.1$ and $39.0 \pm 0.1^{\circ} \mathrm{C}$ in IVP and AI, respectively) and respiratory rate (at birth: $34 \pm 2$ and $31 \pm 2$ breaths/ min in IVP and AI, respectively; in wk 16: $36 \pm 5$ 
and $39 \pm 5$ breaths/min in IVP and AI, respectively) increased $(P<0.05)$ during the study. In contrast, heart rate (at birth: $167 \pm 11$ and $154 \pm 10$ beats/min in IVP and AI, respectively; in wk 16: $118 \pm 5$ and 133 \pm 10 beats/min in IVP and AI, respectively) decreased $(P<0.001)$ during the same period. There were tendencies for group $\times$ time interactions $(P<0.1)$ for rectal temperature and heart rate.

Gestation was longer $(P<0.05)$ in IVP $(298 \pm 2 \mathrm{~d}$ if the in vitro culture period of $7 \mathrm{~d}$ was included) than in AI calves ( $287 \pm 2 \mathrm{~d}$ ), but there was no difference in birth weight between the 2 groups (IVP: $49.7 \pm 1.8$ $\mathrm{kg}$, AI: $46 \pm 2.1 \mathrm{~kg} ; P>0.1$ ). One IVP calf had a birth weight of $63 \mathrm{~kg}$.

In both groups, BW, average daily gain, and average daily feed intake increased $(P<0.001)$ during the study (Figure 1). After a tendency to decrease $(P<0.1)$ during the first $3 \mathrm{wk}$ of life, the gain/feed ratio increased $(P$ $<0.001$ ) from wk 3 to wk 5 and then remained stable to the end of the study. Mean values for daily gain/ feed ratio increased $(P<0.001)$ from mo 1 to mo 2 in both groups and then remained stable for the rest of the study. Body weight during the study tended to be different $(P<0.1)$ between IVP and AI. The BW was higher $(P<0.05)$ in IVP than AI calves from wk 8 to wk 16 . The average daily gain and average daily feed intake were higher $(P<0.05)$ in IVP than AI calves during the whole experiment. In mo 1 , the daily gain/ feed ratio was higher $(P<0.01)$ in IVP than in AI calves. The weekly $\mathrm{kg}$ of DMI/kg of BW $(0.12 \pm 0.003$ and $0.12 \pm 0.003 \mathrm{~kg} / \mathrm{kg}$ in IVP and AI, respectively), gross energy intake/kg of BW (2.19 \pm 0.05 and $2.15 \pm$ $0.05 \mathrm{MJ} / \mathrm{kg}$ in IVP and $\mathrm{AI}$, respectively), and $\mathrm{kg}$ of $\mathrm{CP}$ intake/kg of BW $(0.026 \pm 0.001$ and $0.026 \pm 0.001 \mathrm{~kg} /$ $\mathrm{kg}$ in IVP and AI, respectively) ratio remained stable and were similar in both groups during the study.

In both groups, body length (at birth: $110 \pm 2$ and $105 \pm 2 \mathrm{~cm}$ in IVP and AI, respectively; in wk 17: 142 \pm 3 and $135 \pm 3 \mathrm{~cm}$ in IVP and AI respectively), withers height (at birth: $77 \pm 1$ and $74 \pm 1 \mathrm{~cm}$ in IVP and AI, respectively; in wk 17: $99 \pm 2$ and $101 \pm 4 \mathrm{~cm}$ in IVP and AI, respectively), and chest circumference (at birth: 79 \pm 2 and $79 \pm 1 \mathrm{~cm}$ in IVP and AI, respectively; in wk 17: $117 \pm 2$ and $109 \pm 3 \mathrm{~cm}$ in IVP and AI, respectively) increased $(P<0.001)$ during the study. Body length was greater $(P<0.05)$ in IVP than in AI calves, and chest circumference tended $(P<0.1)$ to be greater in IVP than AI calves. Group $\times$ time interaction for withers height was significant $(P<0.05)$.

\section{Blood Gases and Measures on Acid-Base Balance}

Mean values of $\mathrm{pH}$ and $\mathrm{pO}_{2}$ in IVP and $\mathrm{AI}$ calves increased $(P<0.01)$ from d 1 to 112 , whereas $\mathrm{pCO}_{2}$ decreased $(P<0.001)$ in both groups (Table 2$)$. After an increase $(P<0.05)$ during the first week of life, concentrations of $\mathrm{BE}$ and $\mathrm{HCO}_{3}$ in both groups decreased $(P<0.001)$ for the rest of the experiment. On $\mathrm{d} 1, \mathrm{pH}$ and $\mathrm{BE}$ in females (pH: $7.25 \pm 0.01$; BE: $3 \pm$ $0.9 \mathrm{mmol} / \mathrm{L})$ were higher $(P<0.05)$ than in males $(\mathrm{pH}$ : $7.16 \pm 0.04$; BE: $-0.9 \pm 2 \mathrm{mmol} / \mathrm{L}$ ). There were no significant differences between IVP and AI calves.

\section{Hematological Status}

The hematocrit, hemoglobin, and band neutrophil values decreased $(P<0.001)$ from $d 1$ to 7 and then remained stable for the rest of the study in both groups (Table 3). Erythrocyte and leukocyte numbers decreased during the first week of life $(P<0.001)$ and then increased $(P<0.05)$ until d 112 in IVP and AI calves. During the entire study, mean corpuscular hemoglobin concentration, lymphocyte, and monocyte numbers increased $(P<0.01)$, and mean corpuscular hemoglobin and mean corpuscular volume decreased $(P<0.001)$ in both groups (data not shown). After an increase $(P<0.001)$ from d 1 to 7 , thrombocytes decreased $(P<0.01)$ during the rest of the experiment in IVP and AI. There tended to be a group $\times$ time interaction for lymphocytes $(P<0.1)$. At birth, leukocyte numbers tended to be higher $(P<0.1)$ in males $\left(10.5 \pm 1.2 \times 10^{9} / \mathrm{L}\right)$ than in females $\left(8.3 \pm 0.5 \times 10^{9} / \mathrm{L}\right)$ and on $\mathrm{d} 112$, lymphocyte numbers in males were higher $(P<0.05)$ than in females $(1.7 \pm 0.3$ and $1.3 \pm$ $0.2 \times 10^{9} / \mathrm{L}$ in males and females, respectively). There were no significant differences between IVP and AI calves.

\section{Blood Plasma Metabolite Concentrations}

Preprandial total protein, albumin, glucose, and total cholesterol concentrations increased $(P<0.001)$ from birth to d 112 in both groups (Table 4). Urea and triglyceride concentrations increased $(P<0.001)$ in IVP and AI calves during the first $4 \mathrm{~d}$ of life and then decreased $(P<0.001)$ until d 112 . Creatinine, lactate, and NEFA concentrations decreased $(P<0.001)$ in both groups with increasing age.

There tended to be group $\times$ time interactions for cholesterol $(P<0.1)$. Albumin concentrations tended to be higher $(P<0.1)$ on $d 7$ and were significantly higher $(P<0.01)$ on d 56 in IVP than in AI. On d 3, triglyceride concentrations tended $(P<0.1)$ to be higher in AI than IVP and were significantly higher $(P$ $<0.05$ ) in IVP than AI on d 28. Glucose concentrations tended to be higher $(P<0.1)$ in AI than in IVP between 0830 and $1630 \mathrm{~h}$ on $\mathrm{d} 7$ and 112 . Glucose concentration on $\mathrm{d} 112$ at $0930 \mathrm{~h}$ in $\mathrm{AI}$ was higher $(P<0.001)$ than 

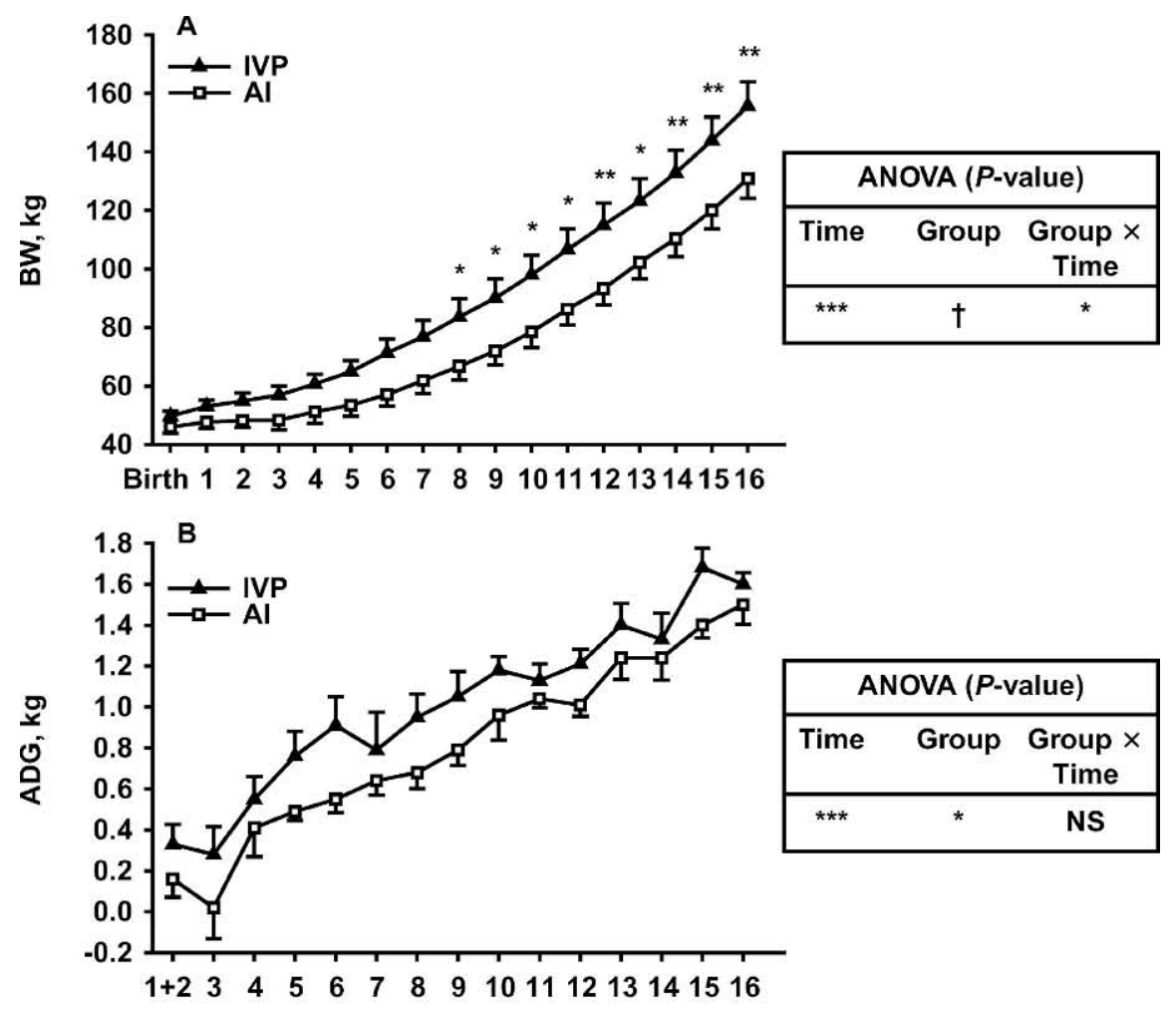

\begin{tabular}{|ccc|}
\hline \multicolumn{3}{|c|}{ ANOVA ( $P$-value) } \\
\hline Time & Group & $\begin{array}{c}\text { Group } \times \\
\text { Time }\end{array}$ \\
\hline$* * *$ & $*$ & NS \\
\hline
\end{tabular}
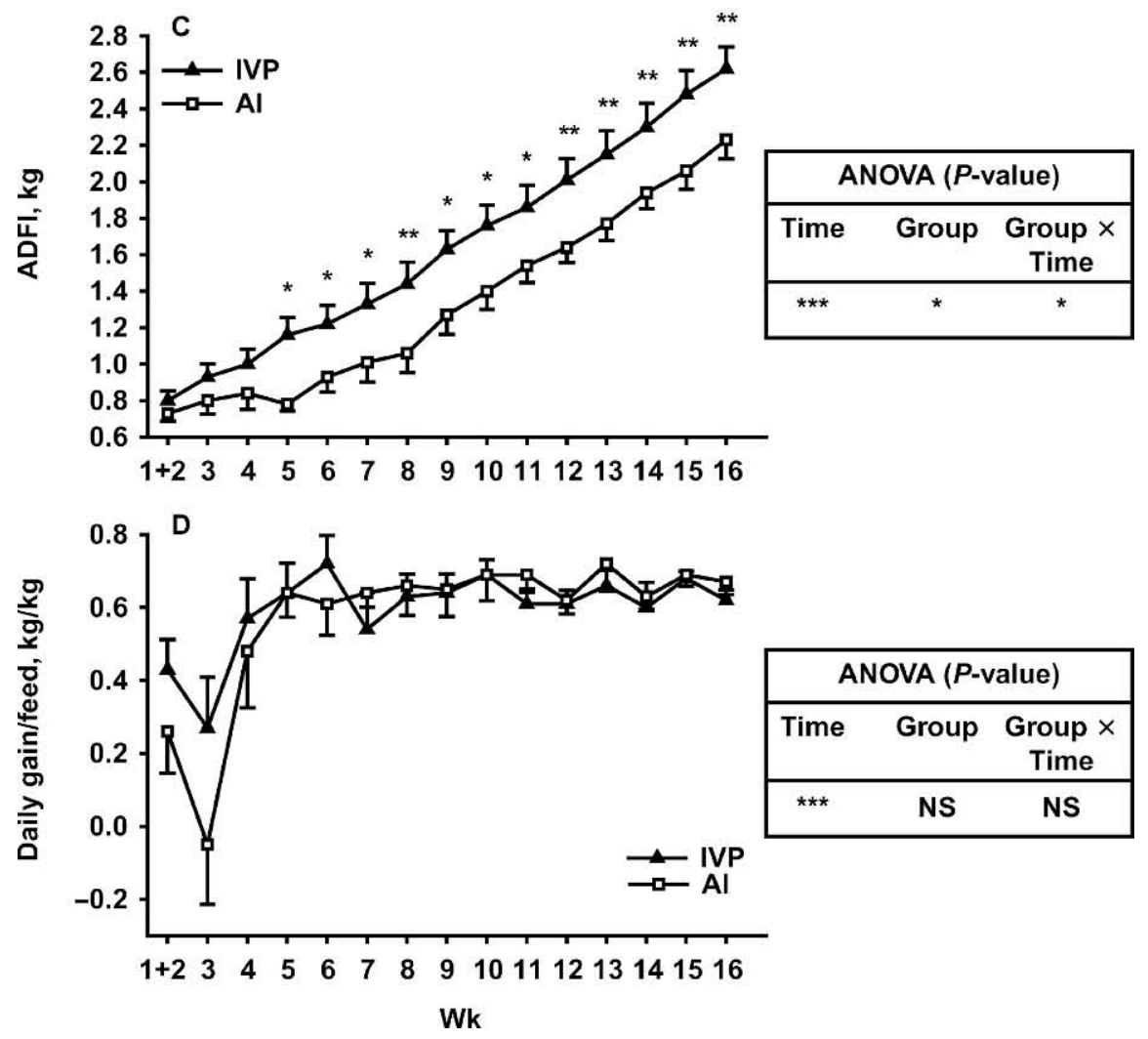

Figure 1. Body weight (A), average daily gain (B), average daily feed intake (C), and daily gain/feed ratio (D) of calves derived from in vitro-produced embryos (IVP; $\mathbf{\Delta}$ ) and from artificial insemination (AI; $\square$ ). Values are means \pm SEM, $n=11$ for the IVP group, $\mathrm{n}=8$ for the AI group. Significance of effects in ANOVA and significance of differences between IVP and AI: NS $=$ not significant, $P \geq 0.1 ; \dagger=P<0.1$; $*=P<0.05 ; * *=P<0.01 ; * * *=P<0.001$. 
Table 2. Blood gases and measures on acid-bases balance of calves derived from in vitro-produced embryos (IVP) and from AI. ${ }^{1}$

\begin{tabular}{|c|c|c|c|c|c|c|c|c|}
\hline \multirow[b]{2}{*}{ Parameter $^{3}$} & \multirow[b]{2}{*}{ Group } & & \multirow[b]{2}{*}{$\begin{array}{l}\text { Pooled } \\
\text { SE }\end{array}$} & \multicolumn{3}{|c|}{ ANOVA $(P \text { value })^{2}$} \\
\hline & & 1 & $\frac{\text { Day }}{7}$ & 112 & & Time & Group & $\begin{array}{l}\text { Group } \\
\times \text { Time }\end{array}$ \\
\hline $\mathrm{pH}$ & $\begin{array}{l}\text { IVP } \\
\text { AI }\end{array}$ & $\begin{array}{l}7.20 \\
7.23\end{array}$ & $\begin{array}{l}7.31 \\
7.34\end{array}$ & $\begin{array}{l}7.32 \\
7.32\end{array}$ & 0.01 & $* * *$ & NS & NS \\
\hline $\mathrm{pCO}_{2}, \mathrm{mmHg}$ & $\begin{array}{l}\text { IVP } \\
\text { AI }\end{array}$ & $\begin{array}{l}75.3 \\
69.3\end{array}$ & $\begin{array}{l}61.5 \\
61.6\end{array}$ & $\begin{array}{l}56.5 \\
56.0\end{array}$ & 1.7 & $* * *$ & NS & NS \\
\hline $\mathrm{pO}_{2}, \mathrm{mmHg}$ & $\begin{array}{l}\text { IVP } \\
\text { AI }\end{array}$ & $\begin{array}{l}26.4 \\
36.3\end{array}$ & $\begin{array}{l}53.7 \\
39.9\end{array}$ & $\begin{array}{l}52.0 \\
46.7\end{array}$ & 4.9 & $* *$ & NS & NS \\
\hline $\mathrm{BE}, \mathrm{mmol} / \mathrm{L}$ & $\begin{array}{l}\text { IVP } \\
\text { AI }\end{array}$ & $\begin{array}{l}1.3 \\
1.5\end{array}$ & $\begin{array}{l}5.0 \\
7.3\end{array}$ & $\begin{array}{l}2.9 \\
2.9\end{array}$ & 0.9 & $* * *$ & NS & $\mathrm{NS}$ \\
\hline $\mathrm{HCO}_{3}, \mathrm{mmol} / \mathrm{L}$ & $\begin{array}{l}\text { IVP } \\
\text { AI }\end{array}$ & $\begin{array}{l}29.3 \\
29.0\end{array}$ & $\begin{array}{l}31.2 \\
33.1\end{array}$ & $\begin{array}{l}29 \\
29\end{array}$ & 0.8 & $* * *$ & NS & NS \\
\hline
\end{tabular}

${ }^{1}$ Values are means; $\mathrm{n}=11$ per IVP group, $\mathrm{n}=8$ per AI group.

${ }^{2}$ Significance of effects in ANOVA and significance of differences between IVP and AI: NS = not significant, $P \geq 0.1 ; \dagger=P<0.1 ; *=P<0.05 ; * *=P<0.01 ; * * *=P<0.001$.

${ }^{3} \mathrm{pCO}_{2}=$ Partial $\mathrm{CO}_{2}$ pressure; $\mathrm{pO}_{2}=$ partial $\mathrm{O}_{2}$ pressure; $\mathrm{BE}=$ base excess.

in IVP $(6.7 \pm 0.4$ and $8.4 \pm 0.5 \mathrm{mmol} / \mathrm{L}$ in IVP and $\mathrm{AI}$, respectively).

Sex significantly affected creatinine concentrations $(P<0.05)$ and tended to affect NEFA concentrations. Albumin concentrations on $\mathrm{d} 1$ were higher $(P<0.05)$ in females than in males $(30.9 \pm 0.5$ and $29.3 \pm 0.5 \mathrm{~g} /$ $\mathrm{L}$, respectively) and on $\mathrm{d} 2$, tended $(P<0.1)$ to be higher in males than females $(27.9 \pm 0.9$ and $29.5 \pm 0.6 \mathrm{~g} / \mathrm{L}$, respectively). Creatinine concentrations at birth were higher $(P<0.001)$ in males than in females $(378 \pm 33$ and $299 \pm 16 \mu \mathrm{mol} / \mathrm{L}$, respectively).
On $\mathrm{d} 7$ and 112, samples were obtained immediately before and at 1,2, 4 , and $8 \mathrm{~h}$ after the start of the feed intake to study changes of plasma glucose, NEFA, and triglycerides. On d 7, there were no significant changes over time of glucose, NEFA, and triglycerides, but glucose tended to be higher $(P<0.1)$ in AI than IVP calves. On d 112, between 0830 and $1630 \mathrm{~h}$, NEFA concentrations decreased $(P<0.01)$ in both groups (at $0830 \mathrm{~h}$ : $0.18 \pm 0.03$ and $0.23 \pm 0.04 \mathrm{mmol} / \mathrm{L}$ in IVP and AI, respectively; at $1630 \mathrm{~h}: 0.13 \pm 0.02$ and $0.13 \pm 0.01$ $\mathrm{mmol} / \mathrm{L}$ in IVP and AI, respectively). On d 122, triglyc-

Table 3. Hematological traits of calves derived from in vitro-produced embryos (IVP) and from AI. ${ }^{1}$

\begin{tabular}{|c|c|c|c|c|c|c|c|c|}
\hline \multirow[b]{3}{*}{ Parameter } & \multirow[b]{3}{*}{ Group } & \multirow{2}{*}{\multicolumn{3}{|c|}{ Day }} & \multirow{3}{*}{$\begin{array}{l}\text { Pooled } \\
\text { SE }\end{array}$} & \multicolumn{3}{|c|}{ ANOVA $(P \text { value })^{2}$} \\
\hline & & & & & & & & Group \\
\hline & & 1 & 7 & 112 & & Time & Group & $\times$ Time \\
\hline \multirow[t]{2}{*}{ Hematocrit, L/L } & IVP & 0.37 & 0.29 & 0.29 & \multirow[t]{2}{*}{0.02} & \multirow{2}{*}{$* * *$} & \multirow[t]{2}{*}{ NS } & \multirow[t]{2}{*}{ NS } \\
\hline & $\mathrm{AI}$ & 0.38 & 0.28 & 0.28 & & & & \\
\hline \multirow[t]{2}{*}{ Hemoglobin, mmol/L } & IVP & 7.1 & 5.8 & 5.9 & \multirow[t]{2}{*}{0.4} & \multirow[t]{2}{*}{$* * *$} & \multirow[t]{2}{*}{ NS } & \multirow[t]{2}{*}{ NS } \\
\hline & $\mathrm{AI}$ & 7.4 & 5.6 & 5.8 & & & & \\
\hline \multirow{2}{*}{ Erythrocytes, $\times 10^{12} / \mathrm{L}$} & IVP & 8.4 & 6.9 & 8.6 & \multirow[t]{2}{*}{0.3} & \multirow[t]{2}{*}{$* * *$} & \multirow{2}{*}{ NS } & \multirow[t]{2}{*}{ NS } \\
\hline & $\mathrm{AI}$ & 8.3 & 6.6 & 8.5 & & & & \\
\hline \multirow[t]{2}{*}{ Leukocytes, $\times 10^{9} / \mathrm{L}$} & IVP & 9.4 & 6.4 & 7.6 & \multirow[t]{2}{*}{0.7} & \multirow[t]{2}{*}{$* * *$} & \multirow[t]{2}{*}{ NS } & \multirow[t]{2}{*}{ NS } \\
\hline & $\mathrm{AI}$ & 9.3 & 7.1 & 8.2 & & & & \\
\hline \multirow[t]{2}{*}{ Band neutrophils, $\times 10^{9} / \mathrm{L}$} & IVP & 6.9 & 2.1 & 2.4 & \multirow[t]{2}{*}{0.5} & \multirow[t]{2}{*}{$* * *$} & \multirow[t]{2}{*}{ NS } & \multirow[t]{2}{*}{ NS } \\
\hline & $\mathrm{AI}$ & 7.5 & 2.3 & 2.1 & & & & \\
\hline \multirow[t]{2}{*}{ Lymphocytes, $\times 10^{9} / \mathrm{L}$} & IVP & 1.8 & 2.9 & 3.7 & \multirow[t]{2}{*}{0.4} & \multirow[t]{2}{*}{$* * *$} & \multirow[t]{2}{*}{ NS } & \multirow[t]{2}{*}{$\dagger$} \\
\hline & $\mathrm{AI}$ & 1.2 & 3.5 & 4.5 & & & & \\
\hline Monocytes, $\times 10^{9} / \mathrm{L}$ & IVP & 0.48 & 0.66 & 1.1 & 0.1 & $* *$ & NS & NS \\
\hline & $\mathrm{AI}$ & 0.49 & 0.60 & 0.8 & & & & \\
\hline Thrombocytes, $\times 10^{9} / \mathrm{L}$ & IVP & 542 & 1095 & 650 & 95 & $* * *$ & NS & NS \\
\hline & $\mathrm{AI}$ & 678 & 843 & 648 & & & & \\
\hline
\end{tabular}

${ }^{1}$ Values are means; $\mathrm{n}=11$ per IVP group, $\mathrm{n}=8$ per AI group.

${ }^{2}$ Significance of effects in ANOVA and significance of differences between IVP and AI: NS = not significant, $P \geq 0.1 ; \dagger=P<0.1 ; *=P<0.05 ; * *=P<0.01 ; * * *=P<0.001$. 
Table 4. Preprandial plasma metabolite concentrations of calves derived from in vitro-produced embryos (IVP) and from AI. ${ }^{1}$

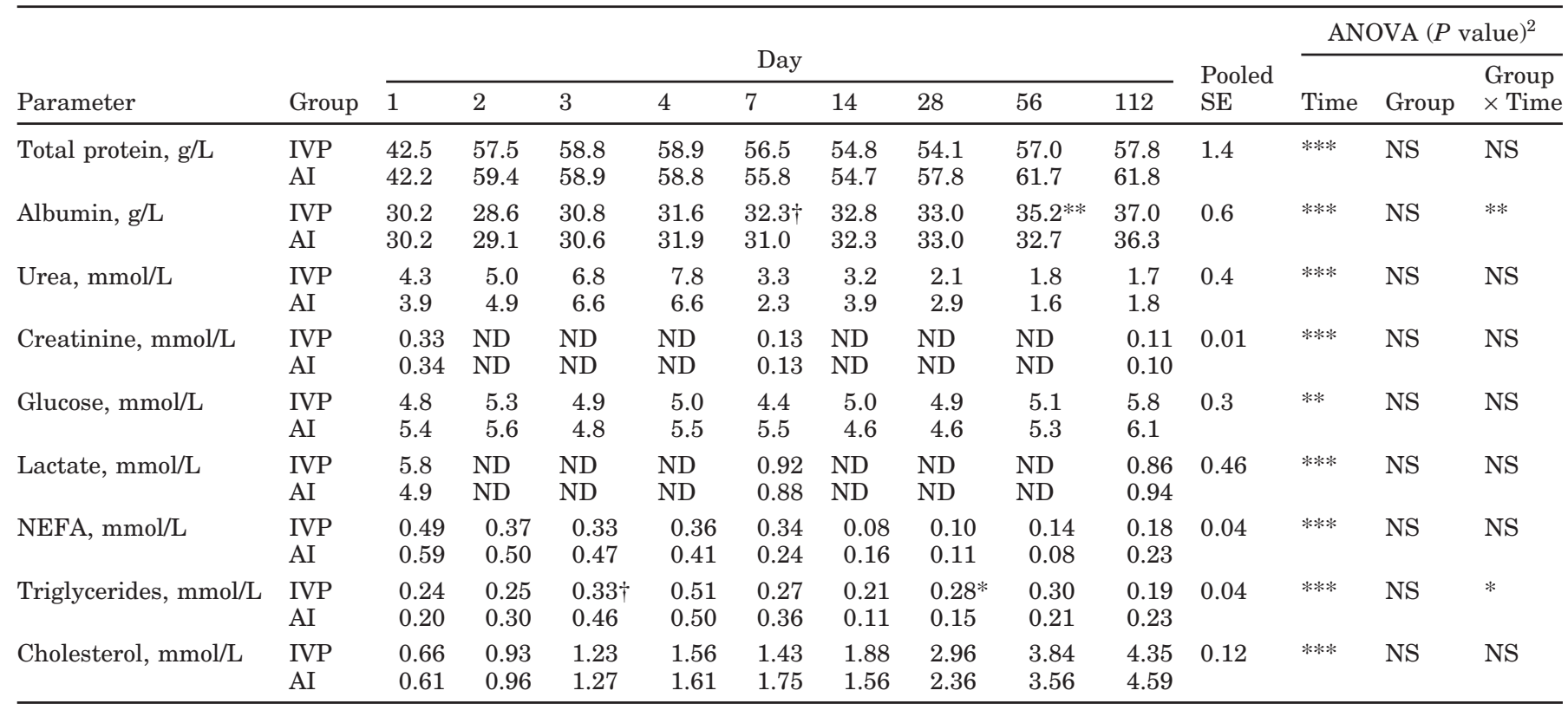

\footnotetext{
${ }^{1}$ Values are means, $\mathrm{n}=11$ per IVP group; $\mathrm{n}=8$ per AI group; ND = not determined.

${ }^{2}$ Significance of effects in ANOVA and significance of differences between IVP and AI: NS $=$ not significant, $P \geq 0.1 ; \dagger=P<0.1 ; *=P<$ $0.05 ; * *=P<0.01 ; * * *=P<0.001$.
}

eride concentrations increased steadily $(P<0.001)$ and glucose concentrations increased transiently $(P<$ 0.001 ) in IVP and AI calves (triglycerides at $0830 \mathrm{~h}$ : $0.19 \pm 0.02$ and $0.23 \pm 0.02 \mathrm{mmol} / \mathrm{L}$ in IVP and AI, respectively; at $1630 \mathrm{~h}: 0.22 \pm 0.03$ and $0.25 \pm 0.04$ $\mathrm{mmol} / \mathrm{L}$ in IVP and AI, respectively). Glucose at 0830 , $0930,1030,1230$, and $1630 \mathrm{~h}$ was $5.8 \pm 0.2$ and $6.1 \pm$ $0.2,6.7 \pm 0.4$ and $8.4 \pm 0.5,6.8 \pm 0.3$ and $7.1 \pm 0.3,6.9$ \pm 0.2 and $6.6 \pm 0.5$, and $6.4 \pm 0.2$ and $7.2 \pm 0.4 \mathrm{mmol} /$ $\mathrm{L}$ in IVP and AI calves, respectively. Glucose concentrations tended to be higher $(P<0.1)$ in AI than IVP and at $0930 \mathrm{~h}$ were higher $(P<0.001)$ in AI than IVP calves. There were significant group $\times$ time interactions $(P<0.01)$ for glucose.

\section{Blood Serum Electrolyte Concentrations}

Preprandial calcium concentrations decreased $(P<$ 0.001) in both groups during the study (Table 5). In contrast, inorganic phosphorus concentrations increased $(P<0.001)$ from birth to d 112 in IVP and AI. Magnesium concentrations decreased $(P<0.001)$ during the whole study in both groups. After a decrease during the first week of life, sodium concentrations increased $(P<0.001)$ in IVP and AI from d 7 to 112 . On d 7 , sodium concentrations were higher $(P<0.05)$ in IVP than in AI. In both groups, chloride concentrations decreased $(P<0.001)$ from $\mathrm{d} 1$ to $\mathrm{d} 7$ and then increased $(P<0.001)$ for the rest of the experiment. Chloride concentrations were higher $(P<0.05)$ on $\mathrm{d} 1$ in females than in males ( $101 \pm 1$ and $98 \pm 1 \mathrm{mmol} / \mathrm{L}$, respectively). Potassium concentrations in IVP were lower $(P<0.05)$ at birth, but were higher $(P<0.05)$ on $d 7$ than in AI. Iron concentrations decreased $(P<0.001)$ from $d 1$ to 4 and then increased $(P<0.001)$ from $d 4$ to 112 in IVP and AI calves.

\section{Blood Plasma Hormone Concentrations}

Insulin concentrations decreased $(P<0.001)$ in both groups from $d 1$ to 7 and then increased $(P<0.001)$ until d 112 (Table 6). Glucagon concentrations increased $(P<0.001)$ from $d 1$ to 2 and then decreased $(P<0.001)$ for the rest of the study in both groups.

Concentration of GH increased $(P<0.01)$ in IVP and AI during the first wk of life and then decreased $(P<$ 0.01 ) from $d 7$ to 112 . On $d 7$, between 0830 and 1630 $\mathrm{h}$, mean GH concentrations were $32.1 \pm 5.4 \mu \mathrm{g} / \mathrm{L}$ in IVP and $26.7 \pm 5 \mu \mathrm{g} / \mathrm{L}$ in AI; basal concentrations were $29.5 \pm 5.4 \mu \mathrm{g} / \mathrm{L}$ in IVP and $21.7 \pm 4.3 \mu \mathrm{g} / \mathrm{L}$ in AI; peak amplitudes were $21.6 \pm 3.4 \mu \mathrm{g} / \mathrm{L}$ in IVP and $27.9 \pm 3.2$ $\mu \mathrm{g} / \mathrm{L}$ in $\mathrm{AI}$; and peak frequencies were $0.003 \pm 0.0005 /$ min in IVP and $0.005 \pm 0.0009 / \mathrm{min}$ in AI. On d 112, between 0830 and $1630 \mathrm{~h}$, mean $\mathrm{GH}$ concentrations were $8.4 \pm 1.3 \mu \mathrm{g} / \mathrm{L}$ in IVP and $6.7 \pm 0.9 \mu \mathrm{g} / \mathrm{L}$ in AI; basal concentrations were $5.2 \pm 0.9 \mu \mathrm{g} / \mathrm{L}$ in IVP and $4.7 \pm 0.8 \mu \mathrm{g} / \mathrm{L}$ in $\mathrm{AI}$; peak amplitudes were $13.2 \pm$ $3.1 \mu \mathrm{g} / \mathrm{L}$ in IVP and $10.1 \pm 1.2 \mu \mathrm{g} / \mathrm{L}$ in $\mathrm{AI}$; and peak 
Table 5. Blood plasma electrolyte concentrations of calves derived from in vitro-produced embryos (IVP) and from AI. ${ }^{1}$

\begin{tabular}{|c|c|c|c|c|c|c|c|c|c|c|c|c|c|c|}
\hline \multirow[b]{3}{*}{ Parameter } & \multirow[b]{3}{*}{ Group } & \multirow{2}{*}{\multicolumn{9}{|c|}{ Day }} & \multirow{3}{*}{$\begin{array}{l}\text { Pooled } \\
\text { SE }\end{array}$} & \multicolumn{3}{|c|}{ ANOVA $(P \text { value })^{2}$} \\
\hline & & & & & & & & & & & & \multirow[b]{2}{*}{ Time } & \multirow[b]{2}{*}{ Group } & \multirow{2}{*}{$\begin{array}{l}\text { Group } \\
\times \text { Time }\end{array}$} \\
\hline & & 1 & 2 & 3 & 4 & 7 & 14 & 28 & 56 & 112 & & & & \\
\hline Calcium, mmol/L & $\mathrm{AI}$ & 2.98 & 2.69 & 2.74 & 2.79 & 2.72 & 2.51 & 2.46 & 2.58 & 2.68 & 0.04 & $* * *$ & NS & NS \\
\hline \multirow[t]{2}{*}{ Phosphorus, mmol/L } & IVP & 2.13 & 2.16 & 2.16 & 2.31 & 2.43 & 2.51 & 2.44 & 2.50 & 2.73 & \multirow[t]{2}{*}{0.06} & \multirow[t]{2}{*}{$* * *$} & \multirow[t]{2}{*}{ NS } & \multirow[t]{2}{*}{ NS } \\
\hline & $\mathrm{AI}$ & 2.08 & 2.29 & 2.33 & 2.34 & 2.40 & 2.31 & 2.35 & 2.48 & 2.71 & & & & \\
\hline \multirow[t]{2}{*}{ Sodium, mmol/L } & IVP & 142 & ND & ND & ND & $133^{*}$ & ND & ND & ND & 136 & \multirow[t]{2}{*}{1} & \multirow[t]{2}{*}{$* * *$} & \multirow[t]{2}{*}{ NS } & \multirow[t]{2}{*}{$*$} \\
\hline & $\mathrm{AI}$ & 143 & ND & ND & ND & 129 & ND & ND & ND & 137 & & & & \\
\hline \multirow[t]{2}{*}{ Potassium, mmol/L } & IVP & $4.5^{*}$ & ND & ND & ND & $5.0 *$ & ND & ND & ND & 4.4 & \multirow[t]{2}{*}{0.1} & \multirow[t]{2}{*}{ NS } & \multirow[t]{2}{*}{ NS } & \multirow[t]{2}{*}{$* *$} \\
\hline & $\mathrm{AI}$ & 4.8 & ND & ND & ND & 4.6 & ND & ND & ND & 4.7 & & & & \\
\hline Chloride, $\mathrm{mmol} / \mathrm{L}$ & IVP & 99 & ND & ND & ND & 95 & ND & ND & ND & 100 & 1 & $* * *$ & NS & NS \\
\hline & $\mathrm{AI}$ & 101 & ND & ND & ND & 92 & ND & ND & ND & 101 & & & & \\
\hline
\end{tabular}

${ }^{1}$ Values are means; $\mathrm{n}=11$ per IVP group, $\mathrm{n}=8$ per AI group; ND = not determined.

${ }^{2}$ Significance of effects in ANOVA and significance of differences between IVP and AI: NS $=$ not significant, $P \geq 0.1 ; \dagger=P<0.1 ; *=P<$ $0.05 ; * *=P<0.01 ; * * *=P<0.001$.

frequencies were $0.007 \pm 0.0007 / \mathrm{min}$ in IVP and 0.005 $\pm 0.001 / \mathrm{min}$ in AI. On d 7, between 0830 and $1630 \mathrm{~h}$, GH peak frequencies tended to be higher $(P<0.1)$ in AI than in IVP and concentrations of GH decreased $(P<0.01)$ in both groups during the same period on $\mathrm{d}$ 112 (at $0830 \mathrm{~h}: 10.4 \pm 1.9$ and $9.1 \pm 1.7 \mu \mathrm{g} / \mathrm{L}$ in IVP and $\mathrm{AI}$, respectively; at $1630 \mathrm{~h}: 5.4 \pm 1.4$ and $6.8 \pm$ $1.1 \mu \mathrm{g} / \mathrm{L}$ in IVP and AI, respectively). The GH peak amplitudes on d 112 tended to be higher $(P<0.1)$ in males than in females (15.7 \pm 3 and $8.6 \pm 1.5 \mu \mathrm{g} /$ $\mathrm{L}$, respectively).

The IGF-I concentrations decreased $(P<0.001)$ in both groups from $\mathrm{d} 1$ to $\mathrm{d} 7$ and then increased $(P<$ $0.001)$ during the rest of the study. There were no significant group differences. In IVP and AI, IGF-II concentrations increased $(P<0.001)$ from $\mathrm{d} 1$ to $\mathrm{d} 2$ and then decreased $(P<0.001)$ during the rest of the experiment. There were no significant group differences.

After an increase from d 1 to $2(P<0.001)$, leptin concentrations decreased $(P<0.001)$ from d 2 to 112 in both groups. Mean concentrations of leptin tended to be higher $(P<0.1)$ in AI than in IVP calves.

Concentrations of $\mathrm{T}_{3}$ and $\mathrm{T}_{4}$ decreased $(P<0.001)$ in both groups during the first week of life and then increased $(P<0.001)$ until d 112. At birth, concentrations of $\mathrm{T}_{3}$ and $\mathrm{T}_{4}$ were higher $(P<0.05)$ in AI than in IVP calves.

On $\mathrm{d} 7$ and 112, blood samples were obtained immediately before, and $1,2,4$, and $8 \mathrm{~h}$ after the start of the feed intake to study changes of plasma concentrations of insulin and glucagon. On d 7 between 0830 and $1630 \mathrm{~h}$, insulin concentrations did not change. On d 112 between 0830 and $1630 \mathrm{~h}$, insulin increased within $1 \mathrm{~h}$ after the availability of food at $0830 \mathrm{~h}$ and then remained elevated $(P<0.001)$ in IVP and AI calves (at $0830 \mathrm{~h}: 0.49 \pm 0.1$ and $0.67 \pm 0.12 \mu \mathrm{g} / \mathrm{L}$ in IVP and AI, respectively; at $1630 \mathrm{~h}: 2.47 \pm 0.84$ and $4.03 \pm 1.39 \mu \mathrm{g} / \mathrm{L}$ in IVP and AI, respectively) and the concentrations in AI were higher $(P<0.05)$ than in IVP. On d 7 and 112, glucagon concentrations increased $(P<0.01)$ in both groups. On $\mathrm{d} 7$ at $0830 \mathrm{~h}$ values were: $113 \pm 15$ and $95 \pm 8 \mathrm{ng} / \mathrm{L}$ in IVP and AI, respectively; and at $1630 \mathrm{~h}: 125 \pm 18$ and $96 \pm 9 \mathrm{ng} / \mathrm{L}$ in IVP and AI, respectively. On d 112 at $0830 \mathrm{~h}$ values were: $79 \pm 5$ and $84 \pm 8 \mathrm{ng} / \mathrm{L}$ in IVP and AI, respectively; and at $1630 \mathrm{~h}: 85 \pm 5$ and $82 \pm 6 \mathrm{ng} / \mathrm{L}$ in IVP and AI, respectively.

\section{DISCUSSION}

\section{Animal Material, Health Status, Gestation Length, Feeding, and Growth Performance}

Oocytes for in vitro fertilization were obtained at random from a heterogeneous population of cows in a slaughterhouse. Oocytes from the different donor cows were pooled before fertilization. Because of the heterogeneity of the donor cows and oocytes, genetic influences on resulting calves from the maternal side can be excluded. On the other hand, the same bull was used to produce IVP and AI calves, which excludes genetic influences from the male side. Embryos were implanted and semen inserted into cows of different breeds, which makes influences from the maternal side 


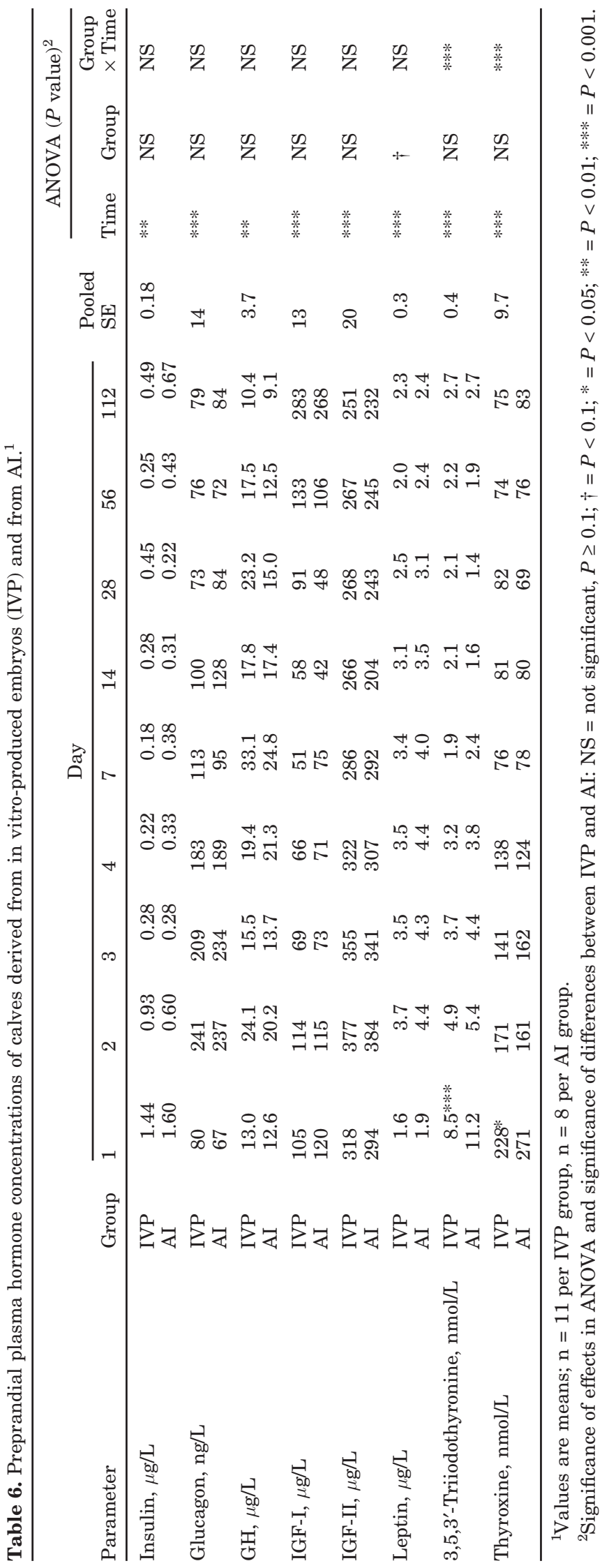

unlikely. In addition, recipient cows for production of IVP and AI calves were held under very controlled husbandry and feeding conditions at a research station, thus minimizing external influences during gestation. This was also true for resulting calves from birth to slaughter.

Perinatal problems such as higher postnatal mortality (van Wagtendonk-de Leeuw et al., 2000) or reduced viability (Sangild et al., 2000) of IVP calves were not observed in our study. Calves were generally healthy and the health status of IVP calves at birth and during the experiment was similar to that of AI calves. Clinical traits such as heart rate, rectal temperature, and respiratory rate were nearly identical in both groups. However, gestation length in IVP was prolonged and this is a typical sign for LOS (Kruip and den Daas, 1997). A reduced number of placentomes during pregnancy of in vitro-produced embryos (Farin and Farin, 1995) may negatively affect feto-maternal communication and this situation could be a reason for prolonged gestation observed in the actual study. The use of serum and cocultured cells in culture medium has been found as a possible cause for the increased birth weight in IVP calves (Jacobsen et al., 2000b; Sinclair et al., 1998). However, in our study, the culture medium was not supplemented with serum and cells, and we have not observed significant differences in birth weight between IVP and AI calves (Jacobsen et al., 1999).

In contrast to the study of McEvoy et al. (1998), BW were significantly higher between wk 8 and wk 16 in IVP than in AI calves, and average daily gains were higher in IVP than AI calves during the whole study. Body length during the first 4 mo of life was higher in IVP than in AI calves. All these results expressed a higher growth performance of IVP than of AI calves during the observation period. Because the amounts of provided feeds depended on BW, the average daily feed intake increased proportionally with BW and was, therefore, higher in IVP than in AI calves. During the whole study, the ratios of ingested feed, energy, and protein per kilogram of BW were similar in IVP and AI calves. Therefore, the IVP calves had a faster growth rate than AI calves under conditions of identical nutrient intakes per kilogram of BW. The greater gain/feed ratios in IVP than AI calves during the first month of life expressed an initially greater efficiency in feed use of IVP than AI calves. These results are in accordance with a study, reviewed by Walker et al. (1996), that initially demonstrated a significantly faster growth rate in lambs born after embryo culture, followed by a decline in growth rate differences up to the age of $7 \mathrm{mo}$. Because children born after in vitro fertilization grow normally up to the age of $18 \mathrm{mo}$ 
(Wennerholm et al., 1998), species differences may exist.

\section{Blood Gases and Acid-Base Balance}

Jacobsen et al. (2000a) found that ease of calving influenced blood parameters of calves at birth. Thus, the higher $\mathrm{pH}$ and $\mathrm{BE}$ values in female than male calves at birth in our study may express easier calving and an improved acid-base homeostasis in the first hours after birth in females than males. The low $\mathrm{pH}$ and $\mathrm{pO}_{2}$ and the high $\mathrm{pCO}_{2}$ at birth of IVP and AI calves reflected birth stress. However, the postnatal ability to restore body temperature and acid-base balance was the same in both groups and thus indicated a similar capacity to adapt to extrauterine life in IVP and AI calves. Respiratory functions of IVP calves were, too, similar as those of AI calves because there were no significant differences between IVP and AI in blood gas measurements and respiratory rates.

\section{Hematological Status}

Hematological values and changes observed in this study were in agreement with previous studies (Egli and Blum, 1998). Hematocrit, hemoglobin concentration, and numbers of erythrocytes and leukocytes (particularly band neutrophils) decreased in IVP and AI calves during the first week of life, in part as a consequence of hemodilution after intake of water with colostrum and MR (Hadorn et al., 1997). The ensuing increases of erythrocyte and leukocyte numbers (particularly of lymphocytes and monocytes) were likely due to increasing erythro- and leucopoiesis. The reasons for higher lymphocyte numbers in male than female calves on d 112 are unknown, but may be occasional. Hematological traits of our study were not different between IVP and AI calves. This was in accordance with Chavatte-Palmer et al. (2002), who found no significant differences in hematologic parameters between cloned and AI calves with the exception of higher mean corpuscular volume in cloned calves.

\section{Blood Plasma Metabolite and Electrolyte Concentrations}

Total protein concentrations markedly increased in both groups after the first feeding due to a high absorption of colostral IgG (Hadorn et al., 1997; Rauprich et al., 2000). Together with total protein, albumin concentrations increased during the whole study, reflecting in part enhanced hepatic synthesis. In IVP calves, the tendency of higher albumin levels on $d 7$ and the higher concentrations of albumin on d 56 sug- gested a higher hepatic albumin synthesis in IVP than in AI. The rise of plasma urea in both groups during the first $4 \mathrm{~d}$ of life mirrored enhanced rates of protein degradation and amino acid deamination after high protein intake (Hammon et al., 2002). Urea concentrations decreased markedly with the change from feeding colostrum to feeding milk on $\mathrm{d} 4$ because of lower protein intake. The rapid fall of creatinine after birth was in accordance with previous studies (Hadorn et al., 1997; Rauprich et al., 2000). Marked renal dysfunction in IVP calves could be excluded because creatinine concentrations decreased similarly as in AI calves. Higher concentrations of creatinine in male than female calves during the experimental period may be explained by the greater muscle mass in males than females (Van Niekerk et al., 1963).

Glucose concentrations were low at birth, but increased after the first feed intake in IVP and AI calves, as shown previously (Hadorn et al., 1997; Hammon and Blum, 1998; Rauprich et al., 2000). The concentrations on d 112 increased between 0830 and $1630 \mathrm{~h}$, in part associated with feed intake that started at 0830 $\mathrm{h}$. The reason(s) for higher glucose concentrations in AI than IVP calves at $0930 \mathrm{~h}$ is (are) unknown. The rapid decrease of lactate concentrations in IVP and AI calves during the first week of life, as shown previosuly (Hadorn et al., 1997; Hammon and Blum, 1998), likely expressed improved aerobic metabolism, and decreased Cori cycle activity.

Concentrations of NEFA were high at birth and then decreased in both groups especially during the first days of life, in agreement with Hadorn et al. (1997) and Hammon and Blum (1998). The changes reflected decreasing fat mobilization, most likely due to enhanced energy intake. The increasing concentrations of cholesterol and triglycerides up to d 4 in IVP and AI calves were likely the result of enhanced fat absorption that in neonatal calves is influenced by amount and time of colostrum ingestion (Blum et al., 1997). When colostrum feeding was changed to MR feeding on d 4, triglyceride concentrations decreased. Higher triglyceride concentrations in IVP than AI calves on $\mathrm{d} 28$ possibly indicated enhanced fat absorption in IVP calves, associated with the higher feed intake. However, triglyceride concentrations in IVP and AI calves were very similar during the experimental period.

The decreasing concentrations of calcium, magnesium, sodium, and chloride during the first week of life in both groups may have been due to hemodilution following ingestion of water with colostrum and milk. Increasing phosphorus concentrations in IVP and AI calves during the experimental period reflected in part the increasing turnover of bone growth. In contrast to other studies (Sangild et al., 2000), the potassium 
concentrations were lower in IVP than AI calves at birth. The cause of higher sodium and potassium concentrations in IVP than AI calves on d 7 is unknown. In IVP and AI calves, hemodilution may also explain the decreasing levels of iron in blood during the first $4 \mathrm{~d}$ of life. During the rest of the experiment, the increasing concentrations of iron most likely resulted from iron injections when the hematocrit was too low and from enhanced iron supply with the MR. Overall, there were no significant differences in electrolyte concentrations between the groups.

\section{Blood Plasma Hormone Concentrations}

Insulin concentrations decreased during the first week of life in IVP and AI calves despite an overall rise of plasma glucose status. On d 112 between 0830 and $1630 \mathrm{~h}$, insulin concentrations increased in both groups in association with increasing glucose concentrations, with a peak in AI calves $1 \mathrm{~h}$ after the first feed intake. The higher postprandial values of insulin in AI than IVP calves on d 112 could be due to individual differences in time of feed intake. Overall, alterations in glucose metabolism between IVP and AI calves were not observed and no differences were found in insulin concentrations, as reported by Jacobsen et al. (2000a) and Chavatte-Palmer et al. (2002). In accordance with other studies (Hammon and Blum, 1998; Rauprich et al., 2000), glucagon concentrations increased after the first meal in both groups. Then, during the rest of the study, increasing concentrations of glucose probably inhibited glucagon secretion in IVP and AI calves.

High GH concentrations in IVP and AI calves during the first week of life indicated that the somatotropic axis has not reached full maturity, in accordance with Hammon and Blum (1997) and Sauter et al. (2003). Concentrations of GH decreased during the rest of the study in both groups, in part because of the increase of nutrient intake and reflecting enhanced maturity of the somatotropic axis. There was a large variation of GH levels between calves on $\mathrm{d} 7$ between 0830 and $1630 \mathrm{~h}$, but the indices of pulsatile secretion of $\mathrm{GH}$ measured on d 7 and 112 did not show significant differences between IVP and AI calves. In opposition to GH, IGF-I concentrations decreased during the first week of life and then increased for the rest of the study in both groups, as shown in other studies (Hadorn et al., 1997; Zimmerli and Blum, 1990). Overall, similar concentrations of GH and IGF-I in IVP and AI calves suggested that the somatotropic system was not different in both groups. This was also true for IGF-II.

In both groups, concentrations of leptin transiently increased after birth, in contrast to another study
(Blum et al., 2005) and then decreased, similar to findings in sheep (McFadin et al., 2002). The postnatal rise may have been due to absorption of ingested colostral leptin or fat and thus energy. The slightly, but not significantly higher leptin concentrations in AI than IVP calves during the whole experiment cannot explain the greater in feed intake in IVP than AI calves. The results do not confirm data from Chavatte-Palmer et al. (2002), who found higher plasma leptin concentrations in cloned than AI calves during the first week of life. The changes in plasma concentrations seen in our veal calves also differed with changes seen in calves that were fed less intensively than our calves fed milk and milk replacers and that were then weaned (Block et al., 2003).

Plasma concentrations of $\mathrm{T}_{3}$ and $\mathrm{T}_{4}$ at birth in IVP calves were lower than in AI calves, in accordance with Garry et al. (1996) and were possibly expressing differences in gestational maturation. The importance of relatively low $\mathrm{T}_{4}$ and $\mathrm{T}_{3}$ levels in IVP calves of the actual study immediately after birth is not clear, but may be related to metabolic rate (Blum et al., 1980, 1985). However, the lower postnatal level of thyroid hormones in IVP calves did not perturb thermoregulatory and other functions of IVP calves because rectal temperatures in IVP and AI calves at birth were similar.

In conclusion, IVP calves, compared with AI calves, were characterized by higher growth performance. However, this was not mirrored by consistent hematologic, metabolic, or endocrine changes. Only at birth were the concentrations of $\mathrm{T}_{3}$ and $\mathrm{T}_{4}$ lower in IVP than AI calves. Whether the lack of problems in IVP calves is also found under field conditions remains to be investigated.

\section{ACKNOWLEDGMENTS}

This investigation was partially supported by Swissgenetics (Zollikofen, Switzerland) and by the Swiss Cattle Breeding Organisations (ASR, Berne, Switzerland).

\section{REFERENCES}

Behboodi, E., G. B. Anderson, R. H. Bon-Durant, S. L. Cargill, B. R. Kreuscher, J. F. Medrano, and J. D. Murray. 1995. Birth of large calves that developed from in vitro-derived bovine embryos. Theriogenology 44:227-232.

Block, S. S., J. M. Smith, R. A. Ehrhardt, M. C. Diaz, R. P. Rhoads, M. E. Van Amburgh, and Y. R. Boisclair. 2003. Nutritional and developmental regulation of plasma leptin in dairy cattle. J. Dairy Sci. 86:3206-3214.

Blum, J. W., M. Gingins, P. Vitins, and H. Bickel. 1980. Thyroid hormone levels related to energy and nitrogen balance during weight loss and regain in adult sheep. Acta Endocrinol. 93:440-447. 
Blum, J. W., U. Hadorn, H. P. Sallman, and W. Schuep. 1997. Delaying colostrum intake by one day impairs plasma lipid, essential fatty acid, carotene, retinol, and $\alpha$-tocopherol status in neonatal calves. J. Nutr. 127:2024-2029.

Blum, J. W., W. Schnyder, P. L. Kunz, A. K. Blom, H. Bickel, and A. Schuerch. 1985. Reduced and compensatory growth: Endocrine and metabolic changes during energy restriction and realimentation in steers. J. Nutr. 115:417-425.

Blum, J. W., Y. Zbinden, H. M. Hammon, and Y. Chilliard. 2005. Plasma leptin status in young calves: Effects of preterm birth, age, glucocorticoid status, suckling, and feeding with an automatic feeder or by bucket. Domest. Anim. Endocrinol. 28:119133.

Chavatte-Palmer, P., Y. Heyman, C. Richard, P. Monget, D. LeBourhis, G. Kann, Y. Chilliard, X. Vignon, and J. P. Renard. 2002. Clinical, hormonal, and hematologic characteristics of bovine calves derived from nuclei from somatic cells. Biol. Reprod. 66:1596-1603.

Egli, C., and J. W. Blum. 1998. Clinical, hematological, metabolic and endocrine traits during the first three months of life of suckling Simmentaler calves held in a cow-calf operation. J. Vet. Med. A Physiol. Pathol. Clin. Med. 45:99-118.

Farin, P. W., and C. E. Farin. 1995. Transfer of bovine embryos produced in vivo or in vitro: Survival and fetal development. Biol. Reprod. 52:676-682.

Garry, F. B., R. Adams, J. P. McCann, and K. G. Odde. 1996. Postnatal characteristics of calves produced by nuclear transfer cloning. Theriogenology 45:141-152.

Hadorn, U., H. Hammon, R. M. Bruckmaier, and J. W. Blum. 1997. Delaying colostrum intake by one day has important effects on metabolic traits and on gastrointestinal and metabolic hormones in neonatal calves. J. Nutr. 127:2011-2023.

Hammon, H., and J. W. Blum. 1997. The somatotropic axis in neonatal calves can be modulated by nutrition, growth hormone, and long-R3-IGF-I. Am. J. Physiol. 273:E130-E138.

Hammon, H., and J. W. Blum. 1998. Metabolic and endocrine traits of neonatal calves are influenced by feeding colostrum for different durations or only milk replacer. J. Nutr. 128:624-632.

Hammon, H. M., G. Schiessler, A. Nussbaum, and J. W. Blum. 2002. Feed intake patterns, growth performance, and metabolic and endocrine traits in calves fed unlimited amounts of colostrum and milk by automate, starting in the neonatal period. J. Dairy Sci. 85:3352-3362.

Hasler, J. F. 2000. In vitro culture of bovine embryos in Menezo's B2 medium with or without coculture and serum: The normalcy of pregnancies and calves resulting from transferred embryos. Anim. Reprod. Sci. 60-61:81-91.

Hasler, J. F., W. B. Henderson, P. J. Hurtgen, Z. Q. Jin, A. D. McCauley, S. A. Mower, B. Neely, L. S. Shuey, J. E. Strokes, and S. A. Trimmer. 1995. Production, freezing and transfer of bovine IVF embryos and subsequent calving results. Theriogenology 43:141-152.

Holm, P., P. J. Booth, M. H. Schmidt, T. Greve, and H. Callesen. 1999. High bovine blastocyst development in a static in vitro production system using SOFaa medium supplemented with sodium citrate and myo-inositol with or without serum-proteins. Theriogenology 52:683-700.

Jacobsen, H., P. Holm, M. Schmidt, P. Sangild, T. Greve, and H. Callesen. 1999. In vitro embryo production versus artificial insemination: Delivery type, birth weight and blood chemistry of the newborn calf. Proc. Annu. Conf. Int. Embryo Transfer Soc., Quebec City, Canada. Theriogenology 51:226. (Abstr.)

Jacobsen, H., P. T. Sangild, M. Schmidt, P. Holm, T. Greve, and H. Callesen. 2002. Macromolecule absorption and cortisol secretion in newborn calves derived from in vitro produced embryos. Anim. Reprod. Sci. 70:1-11.

Jacobsen, H., M. Schmidt, P. Holm, P. T. Sangild, T. Greve, and H. Callesen. 2000a. Ease of calving, blood chemistry, insulin and bovine growth hormone of newborn calves derived from embryos produced in vitro in culture systems with serum and co-culture or with PVA. Theriogenology 54:147-158.
Jacobsen, H., M. Schmidt, P. Holm, P. T. Sangild, G. Vajta, T. Greve, and H. Callesen. 2000b. Body dimensions and birth and organ weights of calves derived from in vitro produced embryos cultured with or without serum and oviduct epithelium cells. Theriogenology 53:1761-1769.

Kruip, Th. A. M., and J. H. G. den Daas. 1997. In vitro produced and cloned embryos: Effects on pregnancy, parturition and offspring. Theriogenology 47:43-52.

Le Gal, F., and A. Massip. 1999. Cryopreservation of cattle oocytes: Effects of meiotic stage, cycloheximide treatment, and vitrification procedure. Cryobiology 38:290-300.

McEvoy, T. G., J. J. Robinson, R. P. Aitken, P. A. Findlay, and I. S. Robertson. 1997. Dietary excesses of urea influence the viability and metabolism of preimplantation sheep embryos and may affect fetal growth among survivors. Anim. Reprod. Sci. 47:71-90.

McEvoy, T. G., K. D. Sinclair, P. J. Broadbent, K. L. Goodhand, and J. J. Robinson. 1998. Post-natal growth and development of Simmental calves derived from in vivo or in vitro embryos. Reprod. Fertil. Dev. 10:459-464.

McFadin, E. L., C. D. Morrison, P. R. Buff, N. C. Whitley, and D. H. Keisler. 2002. Leptin concentrations in periparturient ewes and their subsequent offspring. J. Anim. Sci. 80:738-743.

Merriam, G. R., and K. W. Wachter. 1982. Algorithms for the study of episodic hormone secretion. Am. J. Physiol. 243:E310-E318.

Rauprich, A. B. E., H. Hammon, and J. W. Blum. 2000. Effects of feeding colostrum and a formula with nutrient contents as colostrums on metabolic and endocrine traits in neonatal calves. Biol. Neonate 78:53-64.

Sangild, P. T., M. Schmidt, H. Jacobsen, A. L. Fowden, A. Forhead, B. Avery, and T. Greve. 2000. Blood chemistry, nutrient metabolism, and organ weights in fetal and newborn calves derived from in vitro-produced bovine embryos. Biol. Reprod. 62:1495-1504.

SAS Institute. 1994. Introductory comparison of the GLM and mixed procedure. SAS Inst., Inc., Cary, NC.

Sauter, S. N., E. Ontsouka, B. Roffler, Y. Zbinden, C. Philipona, M. Pfaffl, B. H. Breier, J. W. Blum, and H. M. Hammon. 2003. Effects of dexamethasone and colostrum intake on the somatotropic axis in neonatal calves. Am. J. Physiol. 285:E252-E261.

Schmidt, M., T. Greve, B. Avery, J. F. Beckers, J. Sulon, and H. B. Hansen. 1996. Pregnancies, calves and calf viability after transfer of in vitro produced bovine embryos. Theriogenology 46:527-539.

Sinclair, K. D., T. G. McEvoy, C. Carolan, E. K. Maxfield, C. A. Maltin, L. E. Young, I. Wilmut, J. J. Robinson, and P. J. Broadbent. 1998. Conceptus growth and development following in vitro culture of ovine embryos in media supplemented with bovine sera. Proc. Annu. Conf. Int. Embryo Transfer Soc., Boston, MA. Theriogenology 49:218. (Abstr.)

Taverne, M. A., S. P. Breukelman, Z. Perenyi, S. J. Dieleman, P. L. Vosa, H. H. Jonker, L. de Ruigh, and J. M. van Wagtendonk-de Leeuw. 2002. The monitoring of bovine pregnancies derived from transfer of in vitro produced embryos. Reprod. Nutr. Dev. 42:613-624.

Van Niekerk, B. D. H., J. T. Reid, A. Bensadoun, and D. L. Paladines. 1963. Urinary creatinine as an index of body composition. J. Nutr. 79:463-473.

van Wagtendonk-de Leeuw, A. M., B. J. G. Aerts, and J. H. G. den Daas. 1998. Abnormal offspring following in vitro production of bovine preimplantation embryos: A field study. Theriogenology 49:883-894.

van Wagtendonk-de Leeuw, A. M., E. Mullaart, A. P. W. de Roos, J. S. Merton, J. H. G. den Daas, B. Kemp, and L. de Ruigh. 2000. Effects of different reproduction techniques: AI MOET or IVP, on health and welfare of bovine offspring. Theriogenology 53:575-597.

Walker, S. K., K. M. Hartwich, and R. F. Seamark. 1996. The production of unusually large offspring following embryo manipulation: Concepts and challenges. Theriogenology 45:111-120.

Wennerholm, U. B., K. Albertsson-Wikland, C. Bergh, L. Hamberger, A. Niklasson, L. Nilsson, K. Thiringer, M. Wennergren, M. 
Wikland, and M. P. Borres. 1998. Postnatal growth and health in children born after cryopreservation as embryos. Lancet 351:1085-1090.

Yang, B. S., G. S. Im, and S. J. Park. 2001. Characteristics of Korean native, Hanwoo, calves produced by transfer of in vitro produced embryos. Anim. Reprod. Sci. 67:153-158.

Young, L. E., and H. R. Fairburn. 2000. Improving the safety of embryo technologies: Possible role of genomic imprinting. Theriogenology 53:627-648.
Young, L. E., K. Fernandes, T. G. McEvoy, S. C. Butterwith, C. G. Guttierrez, C. Carolan, P. J. Broadbent, J. J. Robinson, I. Wilmut, and K. D. Sinclair. 2001. Epigenetic change in IGF2R is associated with fetal overgrowth after sheep embryo culture. Nat. Genet. 27:153-154.

Zimmerli, U. V., and J. W. Blum. 1990. Acute and longterm metabolic, endocrine, respiratory, cardiac and skeletal muscle activity changes in response to perorally administered beta-adrenoceptor agonists in calves. J. Anim. Physiol. A Anim. Nutr. $63: 157-172$ 